\title{
Design and Fabrication of Improved Below-Knee Prosthesis to Better Mimic Natural Limb
}

\author{
Ugorji Tochukwu Nze ${ }^{1}$, Osuagwu Chidi Gideon ${ }^{2}$, Ekezie Jervas ${ }^{3 *}$, Igwe Alice ${ }^{1}$ and Okafor Wilson ${ }^{2}$ \\ ${ }^{1}$ Department of Prosthetics and Orthotics, Federal University of Technology, Nigeria \\ ${ }^{2}$ Department of Biomedical Technology, Federal University of Technology, Nigeria \\ ${ }^{3}$ Department of Anatomy, School of Basic Medical Sciences, Federal University of Technology, Nigeria
}

Submission: August 14, 2017; Published: October 26, 2017

*Corresponding author: Ekezie Jervas, Department of Anatomy School of Basic Medical Sciences, Federal University of Technology, P.M.B 1526 Owerri, Nigeria, Tel: +234 806 5430037; Email: ekeziejervas@gmail.com

\begin{abstract}
Prosthesis is an artificial substitute or replacement of a part of the body such as tooth, eye, a facial bone, a hip, a knee or another joint, the leg, an arm. Lower limb prosthesis is device made to replace all or part of the leg or foot. Below-knee prosthesis specifically refers to a lower limb prosthesis that replaces part of the leg that is below the knee joint. Most amputees tend to live a dependent and sedentary life, especially when they cannot function effectively and efficiently with their prostheses. They tend to depend on their children and wards for some of their daily activities because of inability to design and fabricate a device (prosthesis) that will rehabilitate and reintegrate such a person into the society. This sometimes leads to a dormant life style, depression or psychological problems. Following this, there is need to design a prosthesis that will accommodate most functions of a lower limb, hence fully rehabilitate and reintegrate such amputees into the society. Secondly, effective and efficient ambulation is the major challenge faced by amputees. This poses a great challenge to them and the rehabilitation team as well. The focus of this research work is to design and fabricate an improved below-knee prosthesis that will better mimic natural limb in form/shape and function by inclusion of a devised ankle joint in the prosthesis. The main conclusion is that the inclusion of the devised ankle joint enhanced the functionality of the prosthesis, hence a better rehabilitation of the amputee than the conventional prosthesis which has direct pylon-to-foot assemblage without any provision for ankle joint.
\end{abstract}

Keywords: Below-knee prosthesis; Ankle joint; Rehabilitation; Functionality

\section{Introduction}

Prosthetic restoration and rehabilitation of amputees proceeded in a hit-miss fashion until after World War II. At that time, the large number of amputees returning from the armed forces stimulated the US Army and Veterans' Administration to take a hard look at the state of the art. Funds for research became available and for the first time, surgeons and engineers became deeply involved in the study of the problems of amputees. The result of these research included new and detailed information regarding the mechanism of gait, energy expenditure, prosthetic alignment principles, recognition of the causes of gait defects, hand functions and the development of better prosthetic components and techniques. In earlier times, the prosthesis available was made of wood with leather socket that was attached to a leather thigh lacer [1,2].

However, the first people that commercialized design and fabrication of prostheses in New York are the Mark Brothers (D.B and A.A Mark) in 1854 [2]. They secured patent to market prostheses for all levels of lower limb amputation. The philosophy of the design is based on the thorough understanding of the biomechanics of the amputee's gait and uses the ground reaction forces generated to stabilize the knee and ankle joint during swing phase.

The decision to carry out this research work was informed by the fact that most available and locally designed below knee prostheses in our health system do not incorporate most of the functions of ankle joint in both design and function. The inclusion of a functional ankle joint in below knee prostheses has been a great challenge to prosthetists and biomedical engineers. With respect to feet and ankles, clinicians must perform a fine balancing act to provide prosthesis that will accommodate various terrains while providing the dynamics necessary to maintain an efficient gait. Currently, there is no technology in use that replicates the body's natural ability to adapt to variances in terrain while negotiating environmental obstacles [3]. The ankle joint is a hinge joint formed by the distal end of the tibia (condyles) and medial malleolus, the distal end of the fibula (lateral malleolus) and the talus. It is the joint between the foot and the leg [4]. On rocky surfaces, the natural ankle will initiate ground contact with reduced dorsiflexion to provide a relatively 
flatter foot. Patients wearing prosthesis attempt to replicate this strategy but are unable to mimic the ankle angle to match the terrain, presumably due to the reduced range of motion available from the ankle and foot. As a result, a prosthetic foot and ankle mechanism with expanded ranges of ankle motion presents an opportunity to restore vital functions among amputees using lower limb prosthesis [5-11].

\section{Materials}

The fabricated below-knee prosthesis consists of a socket, metal pylon and ankle joint component, padding/suspension materials, screws, bolts and nuts. The materials used for designing these components and the below-knee prosthesis as a whole included: Plaster of Paris (POP) bandage and powder, Plastic polymer laminate (epoxy resin), Reinforcement textile (stockinet), Pelite, foam, Metals, Cosmetic finishing materials, Adhesives [12].

\section{Methodology}

This study seeks to make modifications in the ankle joint component of a below knee prosthesis (Inclusion of a devised ankle joint). A natural ankle joint which consist of the tibial condyles, medial and lateral malleolus and talus have some space in-between them which permits the ankle joint to perform its functions [13-26]. The conventional below knee prosthesis has a socket or pylon-to-foot design, which doesn't provide the arrangement (space) seen in a natural ankle joint, hence limits the functions of the user. This study focuses on incorporation of a devised ankle joint in the design and fabrication of belowknee prosthesis so that it will closely mimic natural limb in form and function. The fabrication processes included: assessment [27,28], impression/measurement taking [29], modification [30], lamination of test/check socket, lamination of new positive cast/model, formation of liners/inserts [30], lamination of definitive socket [31], attachment of socket to pylon and ankle joint/alignment [32,33], prosthesis finishing [34,35], amputee's training and follow-up [36].

\section{Result}

During ambulation, the amputee achieved a maximum of 51 steps and 17 strides per minute, unlike when ambulating with the conventional prosthesis where he achieves a maximum of 36 steps/min and 12 strides/min. Comfort level was satisfactory with no pain and minimal energy expenditure. The amputee also finds it easier and makes it faster to step down from a height (Table 1 \& 2).

Table 1: Result of ambulation achieved by the amputee with the improved prosthesis.

\begin{tabular}{|c|c|c|c|c|c|c|}
\hline Comfort & Energy Expenditure & Pain & Max. No of Strides Per Min. & Max. No of Strides Per Min. & Total Steps & Total Strides \\
\hline Satisfactory & Minimal & No & 51 & 17 & 153 & 51 \\
\hline
\end{tabular}

Table 2: Result of ambulation achieved by the amputee with the conventional prosthesis.

\begin{tabular}{|c|c|c|c|c|c|c|}
\hline Comfort & Energy Expenditure & Pain & Max. No of Strides Per Min. & Max. No of Strides Per Min. & Total Steps & Total Strides \\
\hline Not satisfactory & Moderate & little & 36 & 12 & 108 & 36 \\
\hline
\end{tabular}

\section{Discussion}

Designing and fabricating a functional prosthesis that can take over the functions of an amputated body part without any limitation has been a challenge to Prosthetists and Biomedical engineers. This work looked at incorporating the shock absorption function of the ankle joint in the design and fabrication of a below knee prosthesis by means of a devised ankle joint. The ankle joint was made of sheets of metal plates and springs, which is then connected to the socket through a metal pylon and also to the foot component through metal bolts and nuts. The socket was laminated with layers of stockinet impregnated with resin. The socket is then attached to a metal pylon through metal bolts and nuts. The padding material/liners inside the socket are made with eva-foam. A trans-tibial amputee was fitted with both the improved below knee prosthesis and conventional below knee prosthesis which he used at different times and was allowed to walk with each of them through a distance of $100 \mathrm{~m}$ and observations/evaluations the gait achieved with each of the prostheses were made by noting the different gait parameters at different instances. In the gait achieved with the research/ improved prosthesis, two major gait divisions; stance and swing phases were present and achieved with easy. The amputee attested to; no pain, minimal energy expenditure and moderate comfort and was able to walk without a walking aid as against that witnessed in the conventional prosthesis where he used with a walking aid. A number of 51 steps were taken per minute, 17 strides per minute and a total of 153 steps and 51 strides were taken through the distance which lasted for 3mins with the research/improved below knee prosthesis [37-61].

\section{Conclusion}

Although there have been much researches dedicated to advance the functions of below-knee prosthesis to improve amputee's comfort and rehabilitation. The result suggested that the inclusion of the devised ankle joint enhanced the functionality of the prosthesis, hence a better rehabilitation of the amputee than the conventional prosthesis which has direct pylon-foot assemblage without any provision for ankle joint.

\section{References}

1. Andrysek J (2010) Lower-limb prosthetic technologies in the developing world: A review of literature from 1994-2010. Prosthet Orthot Int 34(4): 378-398.

2. Ann Arbor, Mich, Edwards JW (1960) Orthopaedic appliances atlas: artificial limbs: a consideration of aids employed in the practice of orthopaedic surgery. American Academy of Orthopaedic Surgeons 2: 10. 
3. Armstrong C (2013) Ankle functions, the next frontier for clinical outcomes among lower limb amputees. American Academy of Orthopaedic surgeon 2: 45.

4. Bennett W (1989) Limb prosthetics, Domos publications 43, New York, USA.

5. Bennett W (1988) The Evolution of prosthetic devices: A patient history. Domos publication 48, New York, USA.

6. Brachmann S (2014) The Evolution of prosthetic devices: A patient history. The United States Patent Utility 18021

7. Broca A, Elmslie RC (1918) Artificial Limbs. University of London Press. Ltd, p. XIII (Preface), BBC News, London.

8. Burgess EM (1969) The below-knee amputation: Inter-Clinic Inform Bull 4:1-22.

9. Burgess E, Joseph H (1960) Amputations below the knee: Artif. Limbs 13(1): 1-12.

10. Burgess EM (1967) Immediate postsurgical prosthetics in the management of lower extremity amputees, TR 10-5, Prosthetic and Sensory Aids Service, Veterans Administration. Washington, DC, USA.

11. Chris W (2014) Prosthetic limbs, University College London's centre for biomedical engineering.

12. Compere CL (1968) Early fitting of prostheses following amputation. Surg Clin N Amer 48(1): 215-226.

13. Dolan CM (1968) The army medical biomechanical research laboratory porous laminate patellar-tendon-bearing prosthesis. Artif Limbs 12(1): 25-34

14. Duraiswami PK, Orth M, Tuli SM (1971) 5000 years of orthopaedics in India. Clin Ortho Relat Res 75: 269-280.

15. Ellie C (2010) Prosthesis.

16. Epstein I (1938) The Babylonian Talmud, Shabbath. Soncino Press, London, 1: 312-316.

17. Ficarra BJ (1943) Amputations and prostheses through the centuries. Med Record 156(94): 154-239.

18. Fillauer C (1968) Supracondylar wedge suspension of the P.T.B prosthesis: Orth and Pros 22(2): 39-44.

19. Fliegel C, Feuer SG (2000) Historical development of lower-extremity prostheses. Arch Phys Med Rehab 47(5): 275-285.

20. Friedmann LW (1972) Amputations and prostheses in primitive cultures. Bull Prosthet Res, pp. 105-138.

21. Gillis L (1954) Amputations, Grune \& Stratton. The American journal of surgery 91(2): 304.

22. Gillis L (1954) Amputations, Grune \& Stratton, p. 10.

23. Goldner JL, Frank Clippinger W, Bert Titus R (1967) Use of temporary plaster or plastic pylons preparatory to fitting a permanent above knee or below knee prosthesis. Final Report of Project RD-1363-M, Duke University Medical Center, Durham, North Carolina.

24. Hamontree SE, Howard Tyo J (1968) Twenty months experience with the "PTS". Orth and Pros 22(1): 33-39.

25. Hampton F (1966) Suspension casting for below knee, above-knee, and Syme's amputations. Artif Limbs 10(2): 5-26.

26. Herodotus E, Selincourt A (1954) The histories, the penguin classics. harmondsworth, middlesex, Penguin Books Ltd, pp. 566-567.

27. Hill JT (1968) Manual for preparation of a porous PTB socket with soft distal end, Tech. Rep. 6804, US. Army Medical Biomechanical Research Laboratory, Washington DC, USA.

28. Injured marine's guide to new limbs: BBC News, 10 August 2009. A great video featuring British marine Mark Ormrod, who lost an arm and both legs in 2007 .

29. Jane E (2010) Making artificial limbs for amputees: The fascinating and rewarding life of a prosthetist.

30. Jerrold W (1906) The Complete Poetical Works of Thomas Hood. (Oxford Edition), London, pp. 563-600.

31. Kim MN (2014) Early history of prosthesis, Univie 14.

32. Kirk NT (1944) The development of amputation. Bull Med Libr Assoc 32(2): 132-163.

33. Kuhn GG (1966) Kondylen Bettung Munster am Unter-schenkel Stumpf: "KBM-Prothese". Atlas d'Appareillage Prothetique et Orthopedique, No. 14.

34. Litt BD, Le Roy WN (1961) Prosthetic services USA-1961, American orthotics and prosthetics association, Washington DC, USA.

35. (1957) Lower-Extremity Amputee Research Project, Minutes of symposium on BK prosthetics, University of California, Berkeley.

36. Major RH (1945) A History of Medicine. Springfield, III, Charles C. Thomas 1, p. 67.

37. Mak AFT, Zhang M, Boone DA (2001) State-of-the-art research in lowerlimb prosthetic biomechanics-socket interface: a review. J Rehabil Res Dev 38(2): 161-174.

38. Mark RP (2010) Biomechanics of lower limb prosthetics, Springer Heidelberg Dordrecht London, New York, USA.

39. Marschall K, Robert N (1967) Principles of the patellar tendon supracondylar prosthesis. Orthop Pros Appl J 21(1): 33-38.

40. Marschall K, Robert N (1966) The P.T.S. prosthesis (Complete enclosure of patella and femoral condyles in below knee fittings). Orthop Pros Appl J 20(2): 123-126.

41. McCord CP (1963) Cork legs and iron hands, the early history of artificial limbs. Indust Med Surg 32: 102.

42. Neil B (2011) Bionic hand for 'elective amputation' patient: Bionic hands are now so technologically advanced that some patients are opting to have their defective real hands amputated and replaced. BBC News.

43. Pierquin L (1964) Prothese tibiale a emboitage supracondylien. Atlas d' appareillage prothetique et orthopedique, No. 1.

44. Plumb RE, Fred L (1963) Patella-tendon-bearing below-knee porous socket with soft Silastic distal end. Tech. Rep. 6311, US. Army Medical Biomechanical Research Laboratory, Washington DC, USA.

45. Popp H (1939) Zur Geschichte der Prothesen. Med Welt 13: 961-964.

46. Putti V (1930) Historic Artificial Limbs. New York, USA, pp. 40-43.

47. Radcliffe CW, Foort J (1961) The patellar-tendon-bearing belowknee prosthesis. Biomechanics Laboratory, University of California, Berkeley and San Francisco.

48. Stein AH (1971) Letters to the editor, 5000 years of orthopaedics in India. Clin Orthop 75: 269.

49. Shufeldt RW (1918) Improvements in Artificial Limbs Since the Civil War-As Seen in Examples in the Army Medical Museum. Medical Reviews 24: 643-649.

50. Step by step by Megan Lane. BBC News, 10 July 2006. How amputees learn to walk again.

51. Stuart H (2006) Bionic man: The story of and his artificial foot.

52. (1959) The Staff of the Prosthetics Research Group, Biomechanics Laboratory-University of California, Manual of below knee prosthetics, The Regents of the University of California, USA. 
53. The staff (1969) Veterans administration prosthetics center, directs forming of below-knee patellar-tendon-bearing sockets with a thermoplastic material. Orth Pros 23(1): 36-61.

54. Thomas A, Haddan CC (1945) Amputation Prosthesis: Anatomic and Physiologic Considerations, With Principles of Alignment and Fitting Designed for the Surgeon and Limb Manufacturer. J.B. Lippincott Company, Philadelphia, USA, 5: 11-12.

55. Vanderwerker E, Jacpoc MD (1976) A brief Review of the History of Amputation and Prostheses 15(5): 15-16.

56. Varnada K (2014) Ankle functions, the next frontier for clinical outcomes among lower limb amputees. A review.

57. Wagensteen $0 \mathrm{H}$ (1967) Some highlights in the history of amputation reflecting lessons in wound healing: Bull Hist Med 41: 97-131.
58. Wagensteen CH, Wagensteen SD (1967) Military surgeons and surgery: old and new-an instructive chapter in management of contaminated wounds. Surgery 62(6): 1102-1124.

59. Warren CP (1970) Some aspects of medicine in the Greek bronze age. Med Hist 14(4): 364-377.

60. Wilson BB (1972) The modern history of amputation surgery and artificial limbs. Orthop CIin North Am 3(2): 267-285.

61. Wilson LA, Lyquist E, Radcliffe CW (1968) Air-cushion socket for patellar-tendon-bearing below-knee prosthesis. Tech. Rep. 55, Department of Medicine and Surgery, Veterans Administration, Washington, USA, pp. 5-34.

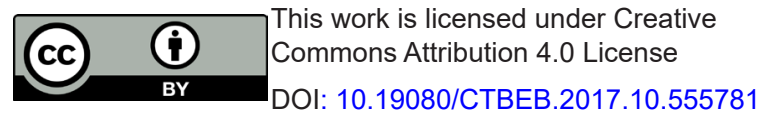

\section{Your next submission with Juniper Publishers} will reach you the below assets

- Quality Editorial service

- Swift Peer Review

- Reprints availability

- E-prints Service

- Manuscript Podcast for convenient understanding

- Global attainment for your research

- Manuscript accessibility in different formats

( Pdf, E-pub, Full Text, Audio)

- Unceasing customer service

Track the below URL for one-step submission https://juniperpublishers.com/online-submission.php 